\title{
THE INFLUENCE OF INDONESIAN NAVY DIPLOMACY THROUGH NAVAL PRESENCE ON THE EFFECTIVENESS OF MARITIME OPERATIONS IN THE NORTH NATUNA SEA
}

\author{
Amarulla Octavian ${ }^{1}$, Priyo Cahyono ${ }^{2}$, Widodo Setiyo Pranowo ${ }^{3,4}$. \\ 1Defense University Maritime Security Study Program, amarulla.octavian@idu.ac.id \\ ${ }^{2}$ Naval Staff and Command School, priyo.cahyono@tnial.mil.id \\ ${ }^{3}$ Research and Marine Center, Ministry of Marine Affairs and Fisheries,widodo.pranowo@kkp.go.id \\ ${ }^{4}$ Hydrographic Study Program of the Naval College of Technology, widodo.pranowo@sttal.ac.id
}

\begin{abstract}
The North Natuna Sea is still a hot topic of discussion both nationally, regionally and internationally. The discussion is inseparable from the interest in the potential of natural resources and energy contained therein. The problems with the boundaries of the Indonesian Exclusive Economic Zone (ZEEI) and the territorial claims in the South China Sea (SCS) by China make this problem more complex so that it is necessary to immediately get serious handling to prevent risks and losses for the national interest. The presence of elements of the naval presence in the North Natuna Sea is a form of handling in the field of maritime operations which aims to maintain maritime security and protect the sovereignty of the Unitary State of the Republic of Indonesia (NKRI) from various threats. Through this article, I would like to provide an overview of Indonesian Navy diplomacy through its naval presence in the North Natuna Sea and its influence on the effectiveness of maritime operations carried out based on the results of research using quantitative methods. Naval presence is part of the Indonesian Navy's diplomacy in dealing with the problems that occur as well as an effort to maintain world recognition of the Republic of Indonesia.
\end{abstract}

Keywords : effectiveness; the presence of elements of the Indonesian Navy, North Natuna Sea; maritime operations

\section{INTRODUCTION}

\subsection{Background}

The North Natuna Sea is part of the Riau Islands region, which is directly adjacent to Malaysia on the West and East sides and Vietnam on the North side. North Natuna Sea is also one of the waters that has the Indonesian Exclusive Economic Zone (ZEEI). ZEEI in the North Natuna Sea has a phenomenal wealth of natural resources, including petroleum, natural gas and fisheries resources. The wealth of natural resources is a great potential for the source of state income as well as for the survival and welfare of the Indonesian nation. The potential of this resource is of higher value because it is supported by the use of the North Natuna Sea as a sea trade route for international ships, especially for trade routes for Asian, European and US countries. Currently, the interests of the state and / or foreign parties in the North Natuna Sea have become increasingly complex and have developed into a conflict or dispute. In this situation, there are at least three main things that are suspected to be the cause of conflict or dispute in these waters, namely: first, the waters of the North Natuna Sea and the group of islands in it contain a very large source of natural wealth which includes mineral resources in the form of oil and gas. land and fishery resources; second, that the territorial waters of the North Natuna Sea are a crossing route for international ships; and third, the economic growth of countries in Asia is getting faster. In this situation, there are at least three main things that are suspected to be the cause of conflict or dispute in these waters, namely: first, the waters of the North Natuna Sea and the group of islands in it contain a very large source of natural wealth which includes mineral resources in the form of oil and gas. land and fishery resources; second, that the territorial waters of the North Natuna Sea are a crossing route for international ships; and third, the economic growth of countries in Asia is getting faster. In this situation, there are at least three main things that are suspected to be the cause of conflict or dispute in these waters, namely: 
first, the waters of the North Natuna Sea and the group of islands in it contain a very large source of natural wealth which includes mineral resources in the form of oil and gas. land and fishery resources; second, that the territorial waters of the North Natuna Sea are a crossing route for international ships; and third, the economic growth of countries in Asia is getting faster. that the territorial waters of the North Natuna Sea are a crossing route for international ships; and third, the economic growth of countries in Asia is getting faster. that the territorial waters of the North Natuna Sea are a crossing route for international ships; and third, the economic growth of countries in Asia is getting faster.

The suspicion of the cause of the dispute in the North Natuna Sea was strengthened by the results of a geological data study and an engineering data study from the Ministry of Energy and Mineral Resources (ESDM) in 2017, it was found that the Natuna region has the largest gas reserves in Asia Pacific with a total of 222 trillion feet. cubic (TCT) and hydrocarbon gas which reached 46 TCT, including petroleum reserves of 298.81 million barrels. This data is also supported by the potential of Natuna capture fisheries based on a study on the identification of potential marine and fishery resources in the Riau Islands Province. In 2014, the utilization of capture fisheries production in Natuna reached more than 233 tons or $46 \%$ of the total potential of sustainable fish resources. In the North Natuna Sea, there are two main commodities of catch fish, namely pelagic fish and demersal fish. Pelagic fish commodity reaches more than 327 tons / year $(80 \%$ of the sustainable potential) with a utilization rate of $37.8 \%$. Demersal fish potential reaches more than 159 tons / year with a utilization rate of 40 tons ( $25.4 \%$ of the sustainable potential), meaning that there are still around 119,209 tons / year (74.6\% that have not been utilized). The phenomenal figures on these two resources are certainly enough to be an excuse for certain parties in realizing their interests.

The importance of naval presence in the North Natuna Sea has increased in line with the development of an increasingly complex situation over the past four years. Based on the data collected, in 2017 there were 347 incidents recorded and decreased in 2018 by 299 incidents. Meanwhile, in 2019, the number of incidents has decreased, reaching 213 cases. This research will describe how the influence of the naval presence in the North Natuna Sea in supporting the effectiveness of the maritime operations being held.

\section{RESEARCH METHOD}

This study uses quantitative methods to determine the level of influence of the naval presence on the effectiveness of maritime operations in the North Natuna Sea. Data were collected through direct research to obtain primary data and secondary data. Primary data was obtained by distributing questionnaires to competent Indonesian Navy officers, both those in charge of regulators and operators in carrying out operations in the North Natuna Sea and then processed using SPSS for windows version 25. Meanwhile, secondary data was collected through literature studies in work units. Indonesian Navy related to the problems studied. The sample used is as many as 84 people who are calculated based on the population using the Slovin formula.

\section{RESULT AND DISCUSSIONS}

The presence of elements of the Navy's operation title in the North Natuna Sea has played a diplomatic function or more commonly referred to as naval diplomacy. The concept of naval diplomacy is relevant to Law No. 34 of 2004 on TNI article 9 paragraph c which explains that the Indonesian Navy has a diplomatic function in supporting Indonesia's foreign policy. This is also in line with Ken Booth's theory of the trinity of the Navy in his book Navies and Foreign Policy. According to Ken Booth, the Navy has three roles (trinity of naval functions), namely a military role, a policing role and a diplomacy role. Naval diplomacy contains three functions in its elaboration, namely the function of negotiating with power, manipulation and prestige.

The function of negotiating with force means that the deployment of Navy forces in negotiations greatly affects the results obtained from the negotiations themselves. The second function is manipulation, which is an effort to create a bargaining position by creating a thirdparty threat and showing the strength of the Navy to the targeted party. Meanwhile, the third function is prestige, which means that the strength of the Navy can create safe conditions for the country with all its interests, maintain and enhance maritime security, and increase the country's value in the environment of international relations and is respected. With this prestige function, the state greatly benefits, automatically a country that has high prestige will tend to be involved in international affairs. High prestige illustrates that a country has the power to solve problems. This will provide a high bargaining position and of course get good diplomatic responses from other countries. Such conditions can be created only if the 
forces possessed and used in operations are relevant forces.

The deployment of Indonesian Navy elements as a form of naval presence as well as diplomacy instruments in the North Natuna Sea has played a major role in supporting the government's political policies. However, until now there has not been much research carried out to describe the extent of the influence of diplomacy carried out by the Indonesian Navy through the naval presence in the North Natuna Sea. The diplomatic potential of the Indonesian Navy needs to be developed to the maximum extent possible to deal with the problems of the North Natuna Sea today considering the strength and capability of Indonesian maritime elements also need to get support from the Indonesian Navy. Therefore,

In the context of upholding law and sovereignty in the North Natuna Sea, the Indonesian Navy does not act alone. The government also has maritime operations, which are organized under ministries and nonmilitary institutions. Maritime operations in the North Natuna Sea are carried out by the Indonesian Maritime Security Agency (Bakamla $\mathrm{RI})$ and the Supervision of Marine Resources and Fisheries (PSDKP). Bakamla $\mathrm{RI}$ is an Indonesian government agency tasked with conducting security and safety patrols in the territorial waters of Indonesia's national jurisdiction based on Republic of Indonesia Law Number 32 of 2014 and Presidential Regulation of the Republic of Indonesia Number 178 of 2014. Bakamla RI also carries out functions of guarding, monitoring, preventing and prosecuting law violations. Especially in the fisheries sector, PSDKP as the government agency under the KKP which is responsible for carrying out supervision in the field of marine and fisheries resources also organizes maritime operations in the North Natuna Sea. The organization, which was formed on 23 November 2000 based on Presidential Regulation No. 63 of 2015, has taken many actions against IUU fishing actors in the North Natuna Sea.

The deployment of Indonesian Navy forces in the North Natuna Sea was carried out through the operation under the command of the Commander of Koarmada I. This operation was held throughout the year by mobilizing various elements. Apart from carrying out the duties of the Indonesian Navy, elements of the Indonesian Naval operations degree are also deployed to provide strength assistance to the maritime operations that are being held.

To be able to measure the extent of the influence of naval presence on maritime operations in the North Natuna Sea, data processing and analysis was carried out through filling out questionnaires by respondents using SPSS 25. The respondents were Indonesian Navy officers who met the required criteria with a sample size of 84 people. of 519 people, the total population is calculated by the Slovin formula. The hypothesis to be tested is "There is a significant influence on naval presence on maritime operations in the North Natuna Sea".

The following are the results of research that illustrates the level of influence of diplomacy through the naval presence by the Indonesian Navy on the effectiveness of maritime operations in the North Natuna Sea:

a. Validity Test Results.

The validity test was carried out on 84 respondents using SPSS for windows version 25 . The validity test is conducted to measure whether a questionnaire is valid or not. Each statement for each variable in the questionnaire is declared valid if rcount> rtable. $r$ table is obtained from calculations using SPSS for windows version 25 with a significance of $5 \%$ is 0.2120 . The results of testing the validity of diplomacy (naval presence) and effectiveness are carried out using the Product Moment correlation technique which is presented in table 1 below:

Table 1 Validity Test Results

\begin{tabular}{|c|c|c|c|c|c|c|c|c|c|c|c|c|c|c|}
\hline & \multicolumn{14}{|c|}{ Correlations } \\
\hline & & $\mathrm{X} 1$ & $\mathrm{x} 2$ & X3 & X4 & $\times 5$ & X6 & X7 & X8 & $\mathrm{x} 9$ & $\mathrm{X} 10$ & $\mathrm{X} 11$ & $\mathrm{X} 12$ & TOTAL_X \\
\hline \multirow[t]{3}{*}{$\mathrm{X} 1$} & $\begin{array}{l}\text { Pearson } \\
\text { Correlation }\end{array}$ & 1 & ,266* & ,252* & 0,127 &, $234^{*}$ & 0,082 & 0,108 & 0,023 & $\begin{array}{r}0,13 \\
0\end{array}$ & 0,108 & 0,023 & 0,130 &, $37 \overline{2}^{\star *}$ \\
\hline & Sig. (2-tailed) & & 0,014 & 0,021 & 0,250 & 0,032 & 0,461 & 0,329 & 0,837 & $\begin{array}{r}0,23 \\
8\end{array}$ & 0,329 & 0,837 & 0,238 & 0,000 \\
\hline & $\mathrm{N}$ & 84 & 84 & 84 & 84 & 84 & 84 & 84 & 84 & 84 & 84 & 84 & 84 & 84 \\
\hline \multirow[t]{3}{*}{$\mathrm{X} 2$} & $\begin{array}{l}\text { Pearson } \\
\text { Correlation }\end{array}$ &, $266^{*}$ & 1 &, $464^{* *}$ &, $343^{* *}$ &, $447^{* *}$ & 0,192 & 0,086 &, $237^{*}$ & 0,176 & 0,086 &, $237^{*}$ & 0,176 &, $577^{* *}$ \\
\hline & Sig. (2-tailed) & $\begin{array}{r}0,01 \\
4\end{array}$ & & 0,000 & 0,001 & 0,000 & 0,079 & 0,439 & 0,030 & 0,110 & 0,439 & 0,030 & 0,110 & 0,000 \\
\hline & $\mathrm{N}$ & 84 & 84 & 84 & 4 & 84 & 84 & 84 & 84 & 84 & 84 & 84 & 84 & 84 \\
\hline $\mathrm{X} 3$ & $\begin{array}{l}\text { Pearson } \\
\text { Correlation }\end{array}$ & ,252* &, $464^{* \star}$ & 1 & ,263* &, $542^{\star *}$ & 0,104 & 0,035 &, $275^{*}$ &, $266^{\star}$ & $-0,035$ &, $275^{*}$ &, $266^{*}$ &, $560^{* *}$ \\
\hline
\end{tabular}


Correlations

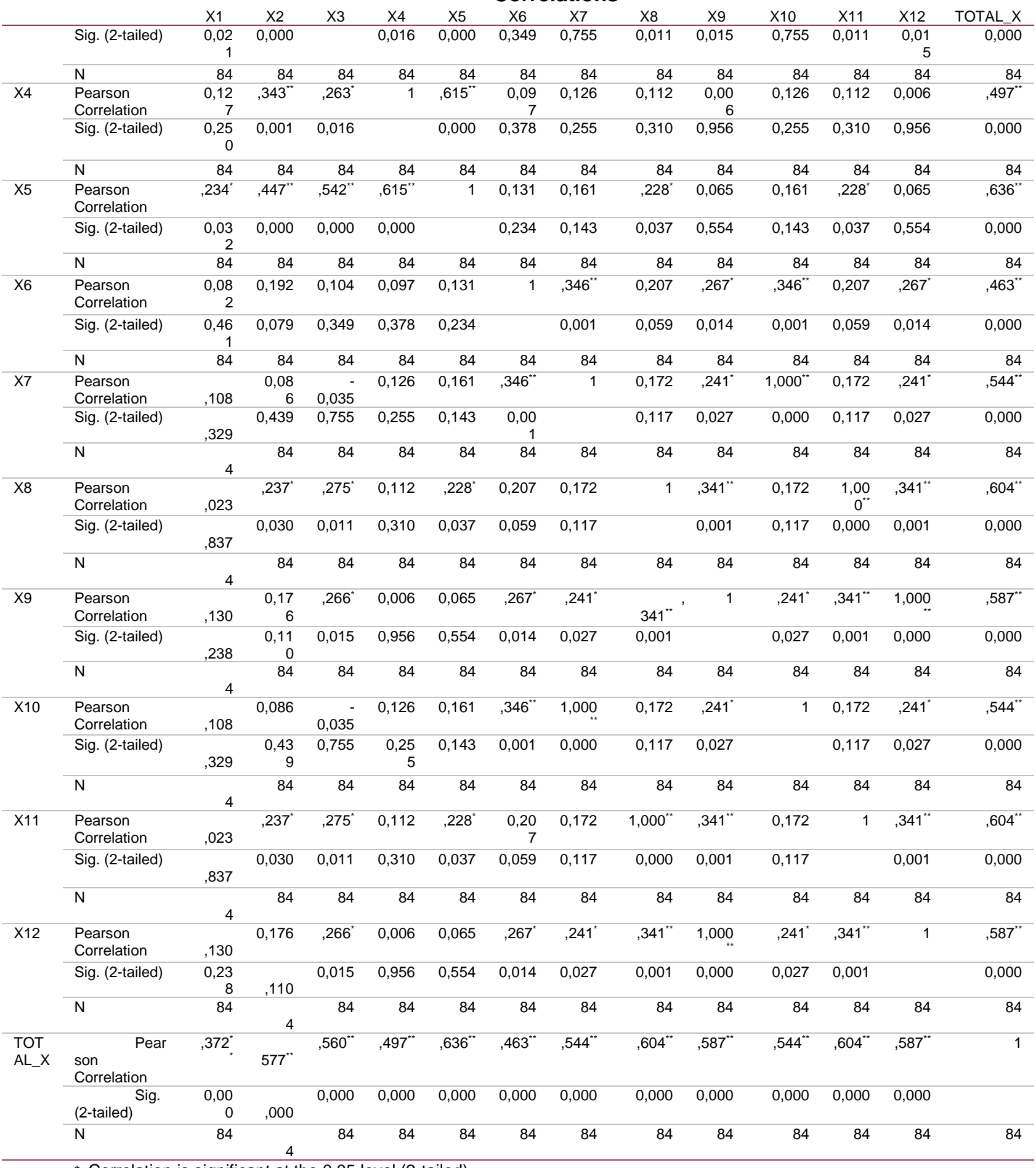

${ }^{*}$. Correlation is significant at the 0.05 level (2-tailed).

Based on table 2 above, all rcount values have a value greater than $r$ table, so that all questionnaire questions/ statements are declared valid.

b. Reliability Test Results

Reliability test is a term used to indicate the extent to which the measurement results are relatively consistent if the measurement is two or more times. The reliability of the data in this study was tested using the Inter-Item
Consistency Reliability which looks at Cronbach's alpha coefficient as the coefficient of reliability. The instrument is considered reliable if it has an alpha $(\alpha)$ coefficient of 0.6 or more.

The basis for decision making for reliable instruments is:

1) If the test alpha ( $\alpha$ ) coefficient is greater than $(\geq) 0.6$, then the statement in the questionnaire is suitable (reliable). 
2) If the coefficient alpha ( $\alpha$ ) the test is less than $(<) 0.6$, then the statement in the questionnaire is not suitable for use (not reliable).
Following are the results of reliability testing with Cronbach's Coefficient Alpha:

\section{Reliabilty Statistics}

\begin{tabular}{crr}
$\begin{array}{c}\text { Cronbach's } \\
\text { Alpha }\end{array}$ & $\begin{array}{c}\text { Cronbach's Alpha } \\
\text { Based on } \\
\text { Standardized Items }\end{array}$ & $\begin{array}{c}\text { N of } \\
\text { Items }\end{array}$ \\
\hline, 772 &, 773 & 12 \\
\hline
\end{tabular}

Based on the results of the reliability test in Table 2 above, the Cronbach's Alpha value obtained is greater than the alpha coefficient (0.06), namely 0.771 . This means that the twelve items of the question / questionnaire statement are appropriate to be used to carry out research. c. Normality Test Results

The normality test aims to see whether the research data is normally distributed or not. If the value is Asymp. Sig. (2-tailed) $>5 \%$ or 0.05 , then the data is considered to be normally distributed and vice versa if Sig. (2-tailed) $<5 \%$ or 0.05 , then the data is considered not normally distributed.

The results of the normality test can be seen in the following table:

Table 3 Normality Test Results

One-Sample Kolmogorov-Smirnov Test

\begin{tabular}{|c|c|c|}
\hline & & $\begin{array}{l}\text { dardized } \\
\text { ed Value }\end{array}$ \\
\hline $\mathrm{N}$ & & 84 \\
\hline \multirow[t]{2}{*}{ Normal Parametersa.b } & Mean & 33.6666667 \\
\hline & Std. Deviation & 2,22834674 \\
\hline \multirow{3}{*}{$\begin{array}{l}\text { Most } \\
\text { Differences }\end{array}$} & Absolute &, 100 \\
\hline & Positive &, 100 \\
\hline & Negative & -0.93 \\
\hline \multicolumn{2}{|l|}{ Statistical Test } &, 100 \\
\hline \multicolumn{2}{|l|}{ Asymp. Sig. (2-tailed) } & $037 c$ \\
\hline
\end{tabular}

a. Test Distribution is Normal

b. Calculated from data

c. Lilliefors Significance Correction

Based on the data processing table above, the significance value is 0.037 . The data is declared to be normally distributed if the significance value is $>0.05$, so that these results indicate that the significance value of 0.037 is greater than 0.05 , then the data is declared to be normally distributed.

d. Data analysis.

Based on the previous test results, the results show that there is a positive correlation 
between naval presence and effectiveness. Furthermore, the results of data processing are continued by carrying out a regression test to obtain a form of analysis model. The basis used is a table of the level of correlation and the strength of the relationship as in the table below:

Table 4 Correlation Level and Relationship Strength

\begin{tabular}{ccc} 
No. & Correlation Value & Relationship Level \\
\hline 1 & $0.00-0.199$ & Very weak \\
\hline 2 & $0.20-0.399$ & Weak \\
\hline 3 & $0.40-0.599$ & Enough \\
\hline 4 & $0.60-0.799$ & Strong \\
\hline 5 & $0.80-1,000$ & Very strong \\
\hline
\end{tabular}

In table 4 above, there is a classification of the level of correlation from zero to number one with the strength of the zero relationship, which is in the "Very Weak" category to number one in the "Very Strong" category.
Furthermore, data that have been declared valid and reliable were analyzed by using multiple linear regression tests using computer aids with SPSS 25 . The results of the data processing are presented in the following table:

Table 5 Model Analysis

Model Summary b

\begin{tabular}{|c|c|c|c|c|}
\hline \multirow{3}{*}{ Model } & \multicolumn{2}{|r|}{$\mathrm{R}$} & Adjusted & \\
\hline & $\mathrm{R}$ & Square & $\mathrm{R}$ & Std. Error of the \\
\hline & & & Square & Estimate \\
\hline
\end{tabular}

a. Predictors: (Constant), Naval Presence

b. Dependent Variable: Effectiveness

The value of the correlation coefficient (R) shows how closely the relationship between the independent variable and the dependent variable is, the value of the correlation coefficient is 0.783 . Based on the classification of values in table 4 (Correlation Level and Relationship Strength), this value indicates that the relationship between naval presence and the effectiveness variable is at a correlation value of $0.80-1,000$ with a strong relationship level.

The coefficient of determination or $\mathrm{R}^{2}$ used to measure how far the model's ability to explain the variation in the dependent variable. The results of the calculation as in table 5 above, obtained the value of $\mathrm{R} 2=0.614$, which means that the ability of the diplomacy model through the naval presence variable has an effect of $61.4 \%$ on effectiveness, while the remaining $38.6 \%$ is influenced by other variables outside the model under study.

\section{Conclusions}

Based on the results of the analysis with SPSS for windows version 25, the level of influence of Indonesian Navy diplomacy through the naval presence (R2) has a value of $61.4 \%$ on the effectiveness of maritime operations in the North Natuna Sea. So, it can be concluded that the presence of elements of the Indonesian Navy in the North Natuna Sea is able to provide a considerable influence. This also means that there are $38.6 \%$ other factors outside of this study that also have an influence on the effectiveness of maritime operations in the North Natuna Sea. However, the level of influence of the Indonesian Navy's diplomacy through the naval presence can still be increased through other means, namely increasing the strength and ability of elements of the Indonesian Navy as well as increasing the frequency of attendance and adding elements of the operational degree. 


\section{ACKNOWLEDGEMENT}

The authors greatly acknowledge the support from Defense University Maritime Security Study Program, Bogor, Indonesia for providing the necessary resources to carry out this research work. The authors are also grateful to Indonesian Naval Technology College, STTAL Surabaya and the anonymous reviewers and journal editorial board for their many insightful comments, which have significantly improved this article.

\section{REFERENCES}

Booth, Ken (1977). Navies and Foreign Policy. London: Routledge.

Directorate General of Oil and Gas, Ministry of Energy and Mineral Resources (2017). Annual Development Achievement Report: Strategy to Excite National Oil and Gas Investment.

Ministry of Marine Affairs and Fisheries of the Republic of Indonesia (2015). Regulation of the Minister of Marine Affairs and Fisheries of the Republic of Indonesia Number 23 / Permen-KP / 2015, Jakarta: State Secretariat of the Republic of Indonesia.

Ministry of Maritime Affairs and Fisheries of the Republic of Indonesia. (2019). Natuna Integrated Marine and Fisheries Center, Jakarta.

State Secretariat of the Republic of Indonesia (2014). Presidential Regulation of the Republic of Indonesia Number 178, Jakarta.

Siregar, Syofian. (2015). Parametric Statistics for Quantitative Research. Jakarta: Earth Literacy. 